\title{
Eco-city or "steady city" as the way of improvement of living conditions for urban population
}

\author{
Elena Vasilyeva ${ }^{1, *}$ \\ ${ }^{1}$ Moscow State University of Civil Engineering, 129337, 26, Yaroslavskoye Shosse, Moscow, Russia
}

\begin{abstract}
The article is devoted to the creation and development of ecocities, also known as "steady cities". Experience of creation of the eco-cities in the countries of the world is analyzed during the research. Classification of the eco-cities is offered. The basic principles of eco-cities functioning are considered; Special attention is paid to the formation of the closed production cycle with the maximum return to technological processes and the use of energy saving technologies. According to the author, creation and development of such settlements will make a great contribution to the solution of environmental problems of modern Europe. Improvement of the environment, quality of living conditions of humans, improvement of the population health and providing a healthy lifestyle are possible within the eco-cities. The author believes, that creation of eco-cities is possible in Russia (some examples of the first projects are given). But the author emphasizes, that in our country this tendency is just being started and besides it has no legislative regulation and state support.
\end{abstract}

\section{Introduction}

Modern city represents a powerful technical infrastructure. Cities are the source of development of a civilization and at the same time, they became one of the main phenomenon, responsible for degradation of the environment. In the modern cities the main part of all resources obtained, is spent. Importance of such transformation of the cities, when only ecological technologies for activity maintenance are used, is determined by it. It is necessary to make "ecological" reconstruction of the cities that the cities provided high quality of life for people not to the detriment of the planet nature for further development.

Eco-city, or stable city is a settlement, designed taking into account the influence on the environment. In such a city inhabitants seek to minimize their consumption of energy, water and food, to exclude irrational allocation of heat, air pollution by carbon dioxide $(\mathrm{CO} 2)$ and methane and also water pollution.

In Europe, environmental problems of settlements have been alarming for long. Owing to dense population, the issues of ecological reconstruction of the housing estate are relevant.

In the countries of North and South America, as well as in Australia great territorial resources and rather satisfactory ecological situation allow to deal with smaller activity with

\footnotetext{
*Corresponding author: elena.chibisova_metr@mail.ru
} 
these issues. Widely the private charity organizations, supporting this process, work, groups of so-called "green" and other organizations of ecological orientation are engaged in the construction of eco-villages.

In Russia and the CIS countries having quite considerable reserve of ecological, natural and territorial resources, the process also has not found support of government institutions yet, it develops by the efforts of individuals and some organizations. Theoretical questions of greening and methods of its implementation at the large city planning level are quite actively discussed in the scientific press and at various conferences. However, practical activities in this area did not come to the city planning level yet $[1,2]$.

In modern economy there is no unambiguous determination of the term "eco-city" in the scientific use. The term of eco-city was introduced by the American constructor and ecologist Richard Redgister in 1978 for the first time. According to the scientist, eco-city is the environmentally friendly city.

Later the contribution to the development of the subject of eco-city was made by A.N. Tetior, Vang Rusong, Fam An Fyong, etc.

The steady city can support itself with the minimum dependence on the surrounding area, and to make energy by the means of renewable sources. The main aspiration of the population of an eco-city is the reduction of the carbon trace.

\section{Methods}

Examples of full transformation of these or those urban areas are known all around the world. Modern practice of the creation of eco-city has been developed since the beginning of the 1960th. Generally, it has found wide distribution in the countries of Europe, North America, and Australia. However, the European countries, in particular Sweden and Denmark were the most active in the field of ecological construction. Germany, Belgium and Norway participate in this process. In general, almost all the European countries have joined the process of greening of their cities [3].

Moreland (Australia). The urban area Moreland in the north of Melbourne has the programme for transformation into the "carbon-free" territory. There are other introductions and offers on transformation into the stable city as well.

Urban area Melbourne. For the last 10 years, the set of measures for the improvement of public transport has been carried out there and zones and the whole streets, free from cars, have been created.

Freiburg (Germany) is often referred to as the green city. It is known for its effective solar economy. The Region of Vauban represents model of the stable city. Houses are under construction, counting upon low level of consumption of energy, and all the area is designed as "carless".

In the end of 2007 the city council of the Southern Dublin (Ireland) has announced its plans to construct Klonburris, the new suburb of Dublin including up to 15000 new houses, which will be designed, taking into account the highest international standards. The plan of creation of Klonburris contains a set of green innovations, such as high level of energy efficiency, obligatory renewables for heating and electricity generation, the use of secondary and stable construction materials, the systems of the centralized heat supply, allocations for production of food, and even the ban of dryer drums (instead of them the application of natural drying is offered).

In 2010 Calgary (Canada) has taken the top place in the rating of the eco-cities of the planet for "the excellent level of service for waste disposal, the system of the sewerage and water supply, in combination with rather low air pollution". Examination has been conducted by authoritative firm on monitoring of quality of life Myorser. 
Eco-city Dongtan on the third largest island of China in the mouth of the Yangtze River near Shanghai. According to the project of the city it was planned to have placed 50 thousand inhabitants by 2010 , however its developer is detaining construction now.

Bulltrout (Sweden) is perhaps, one of the most interesting examples. In Sweden the issues of greening of the way of life are resolved at the state level. In 1993 the government has approved the "Law on eco-cycles", which has determined the beginning of a new phase by environmental protection, introduction of "a waste-free way of life". The Law tells about need "to study at the nature and to change the design ideology from linear to eco-cyclic. According to the representation of the Swedish experts, eco-city is a social and technical system with local waste recycling, sewerages, waste-free technologies for heat and water supply, power supply, the use of solar energy.

It is possible to give an example of complete eco-city, in which the principles of socialand-architectural ecology are rather fully realized. That example is the city of Malmo constructed in 2007.

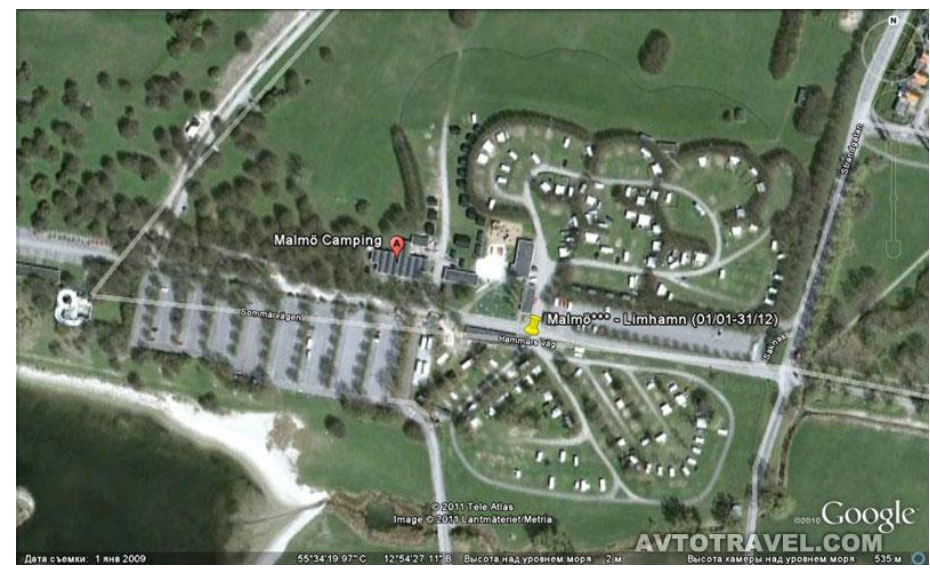

Fig. 1. The city of Malmo.

The decrease in emissions of carbon dioxide by 2012 for $25 \%$ in comparison with 1990 became one of the main tasks of reconstruction of Malmo in an eco-city. The objectives will be achieved by the means of the use of new construction technologies, development of public transport, transition of car owners to hybrid transport and electric cars, advances of alternative power engineering and energy saving technologies.

Replanning of the city is conducted according to the areas. One of the first to be allocated was the western district of the city, in which the port and ship docks are located. This part of the city has to provide completely the needs for power at the expense of renewable sources. It is planned "to save" the port area, thanks to new schemes of transportation, which will reduce the dependence of port on road haulage. The bicycle will be the main city transport.

In Malmo, the solar power is widespread, it is the third city in Sweden according to the number of the used solar batteries. As for figures, it is about 3.4 thousand $\mathrm{m}^{2}$ of solar batteries with a cumulative power of $500 \mathrm{~kW}$. This electricity is more expensive, than what is made by nuclear power plants. Swedes look forward, believing, that solar electricity will become favourable economically soon.

Solar batteries were fixed in the schools, hospitals, pools, museums and other facilities of municipal property, proving, that the state begins to change the world around, starting with itself and thus changing the opinion of the citizens and accustoming them to the idea of the need and expediency of transition to alternative energy sources $[4,5,6]$.

Solar energy in Malmo is used in two ways:

1) for electricity generation (photovoltaic cells), 
2) for heating of water, which is used for domestic needs and for heating (solar collectors).

Modernization of the city of Malmo is not the commercial project. Thus, the Swedish government hopes to increase the interest of the public around the world to renewables and to give an impetus in the development of scientific research in this branch.

In Sweden a wide range of the principles of ecological architecture and construction is realized: energy saving, solar power, autonomous life support systems, intensive agriculture and gardening, environmentally friendly construction materials, taking into account their further recycling, socialization of the living environment is conducted, etc.

In Russia there is its own history of creation of eco-cities.

In the beginning of the 80th the "Eco-police" programme, in which scientists of biological and ecological specialties actively participated, has was developed. According to the concept of the Eco-police programme is a settlement of new type, which develops according to the course of natural processes. In this case, the main efforts were made for the improvement of the natural basis of the city the urban and natural landscapes. Besides, the social environment of the city was formed, educational and information activities among the population were conducted. There were no noticeable measures of city planning character. The implementation of the programme is still continuing now.

Since the beginning of the 90th in Novosibirsk the "Eco-house" programme has been developed. The programme purpose is to transfer all the construction of individual housing in the Novosibirsk region to the construction of energy efficient, ecological housing and at the same time to begin reconstruction of the existing dwellings with the use of ecologically friendly technologies. The initial stage of official realization of this work in practice is the adoption of the programme development of the energy efficient, ecological housing construction in the Novosibirsk suburb in 1999.

Construction of the individual houses, designed on the principles of ecological architecture is provided in the programme. Several projects, realizing eco-housing ideology on the example of one-family houses with the personal plot were developed. According to the offered concept, the ecological housing is friendly to the surrounding environment, comfortable, very warm individual or blocked house with personal plots. Eco-houses are equipped with their own system of heating, using in addition to usual, solar heating of the house and solar heating of water for domestic needs. Therefore, at the first stage the concept of the eco-house so far providing only decrease in load of the environment was formulated [7].

From the middle of the 90th, the international project "Ecological Cities of the Future" is carried out. Within this project the events for greening of the historical cities of Russia, such as Tobolsk, Kirishi, Tikhvin, etc. are held. The concept of greening, put in the project, will be generally agreed with the universal tendencies of transition to the sustainable development of settlements.

New Stupino (Russia) is the first eco-city under designing in Russia. The project is developed by the Russian developer company MR Group. It is the Russia's first full-fledged low satellite-town with affordable housing, jobs and with the developed infrastructure for 55 000 citizens. The city will be located in $70 \mathrm{~km}$ from Moscow Circle Hignway on the highway M4 "Don".

There are no realized projects of eco-city or carrying out eco-reconstruction of the cities in modern comprehension in Russia yet. Nevertheless, some organizations, specializing in ecological housing construction, have closely approached their creation.

The known design methods of the steady cities include [8-11]:

- Creation of various agricultural structures, sites within the city (in the centre or in the suburbs) to reduce the way of food from the place of growth to the end consumer;

- The use of renewables: wind generators, solar batteries or the biogas, created from sewage; 
- Various methods of decrease in the need of air conditioning, such as planting of trees (shading) and colour illumination of the surface, the device of natural ventilation systems, increase in water objects and green zones up to level not less than $20 \%$ from the square of the city. These measures are directed also to fight against "effect of the thermal island" caused by abundance of concrete and asphalt which do urban areas several degrees warmer, than surrounding rural areas;

- Improvement of the public transport work and the increase in pedestrian zones (creation of public spaces) for the reduction of automobile exhausts;

- The optimum density of building to make public transport viable, but to avoid creation of city islands of heat;

- Reduction of growth of the cities, search of the new ways allowing to bring closer as much as possible the place of residence of the population to points of application of work;

- Green roofs;

- Transport with zero level of emissions;

- Active house;

- Steady city drainage systems;

- Energy saving systems / devices;

- Garden and landscape design with pure preservation.

\section{Results}

The analysis of the available examples of eco-cities allows to allocate the following types.

1. "Green" eco-cities. The purpose consists in the increase or preservation of the city environment, i.e. environment was more green, more various, more friendly for the city inhabitants. The main tasks are the increase in quantity and quality of pedestrian zones, preservation of the farmland, identification of ecologically sensitive areas, creation of natural parks for the rest of citizens.

2. Eco-cities "The overcoming limits" - the cities, concerned by overcoming biophysical limits, that economic growth and increased consumption level could be steady. Problems of the cities of this type concern the shortage of the earth under housing construction, air pollution, deficiencies of pure water, the crowded roads, places for burying, deterioration of water in the local river or the lake, and concerns on the increasing expenses and unreliability of energy and fuel. Thus, the emphasis is placed on increase in capacity of an infrastructure for the purpose of the satisfaction of long-term plans of rather economic growth. The main task of this type of an eco-city is the developed transport infrastructure, the system of water supply and the sewerage, waste recycling. It has to lead to smaller pollution of the air and water environment.

3. "Healthy" eco-cities, which are the cities, including the elements of sustainable development, recognizing the right of future generations in plans of the development. Thus, planning of eco-city becomes the expansion of social policy of the state. Historically the city environment was always removed on backgrounds in effort to achieve short-term social-andeconomic objectives. The third type includes economic-and-social benefits at simultaneous ensuring long-term ecological health, resource management and adaptability of the environment.

Thus, the problem of eco-city is the providing a healthy lifestyle and quality life of the inhabitants of the city, of the region, of the country and of the planet as whole.

The basic principles of functioning of an eco-city have to include:

- work of the industrial enterprises in the form of the closed cycle with the maximum return to technological processes of the formed gaseous, liquid and solid waste; ensuring processing of household waste (Fig. 1); 


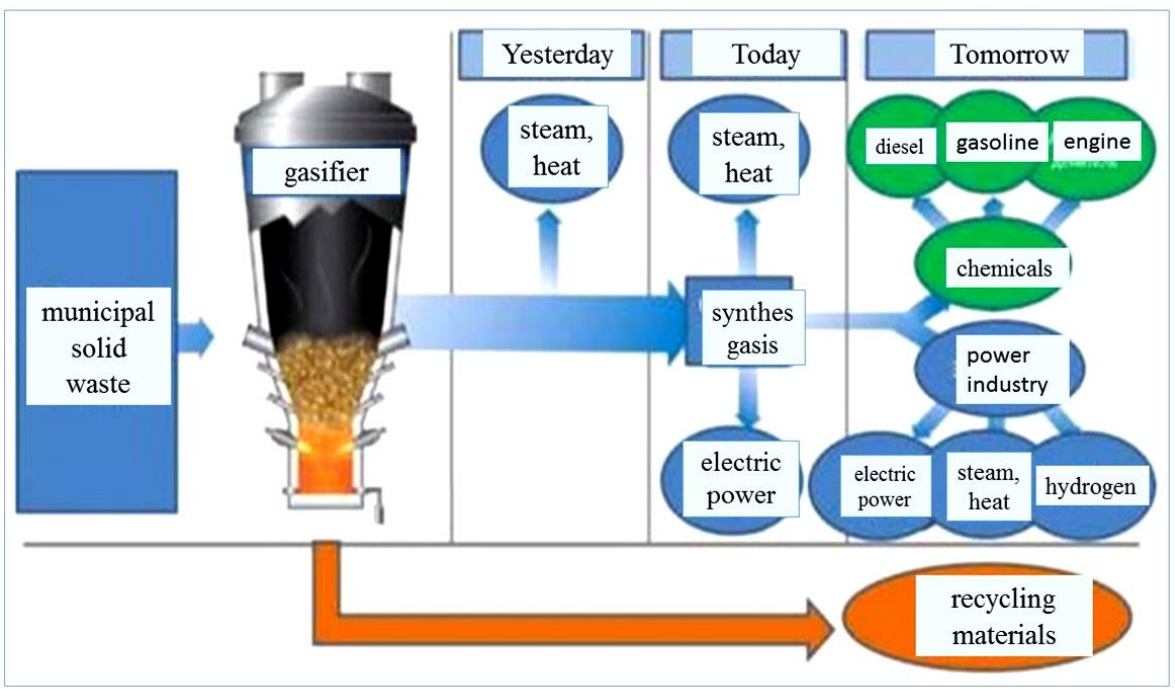

Fig. 2. Closed cycle with the maximum return of the eco-cities.

- the use of energy saving technologies;

- the use of the eco-friendly motor transport;

- construction of low buildings, the use of underground space for the device of warehouses, garages, parking, accumulators of thermal energy and gardening of vertical and horizontal surfaces of buildings and constructions (roofs lawns, walls lawns, the planted trees and shrubs fencings, lighting columns);

- design of apartments with exits in winter gardens, on verandas, creations of the cosy, planted trees and shrubs yards with arbours and collective orchards;

- participation of each resident in design, construction and finishing of the eco-house;

- creation of the eco-centre for ecological education and education of the population with cinema halls, lecture audiences, exhibitions, the video centres, eco-game stores, zoos, aquariums, greenhouses.

\section{Discussion}

Now the Redgister's definition began to be considered in broader sense and determine ecocity as the city, which is capable to provide independently itself with food and energy, at the same time the area, aloof for construction and, therefore, a residential zone, has to be, whenever possible, minimum.

According to the Russian scientist A.N. Tetior, eco-city is the city, built on the principles of environmental friendliness, which is in ecological equilibrium with the nature and not torn away by natural eco-systems, not polluting the nature and penetrated by the green channels with niches for life of wild animals, with eco-friendly buildings and greening of all the activity of citizens, with high quality of life, the system of ecological education, education and involvement of all inhabitants in process of greening of their life and activity.

One of the Chinese researchers of the concept of an eco-city, professor of the Beijing Research Centre of Ecological Sciences Vang Rusong defines it as the administrative unit, having economically productive and ecologically effective industry, systematically responsible and socially harmonious culture, both physically beautiful and functionally recovered landscape. The purpose of development of eco-city, according to him, consists in planning, design and constructions of structurally uniform city, considering process of its 
metabolism and functional stability by cultivation of the ecological landscape, the ecofriendly industry and eco-friendly culture $[12,13]$. In Western Europe goverment actively takes part and processes of greening of the cities. The laws, aimed on the solution of these matters are issued (for example, in Sweden), the policy of subsidizing of scientific research is conducted, financial, organizational and legal support of the persons and the organizations, participating in construction and reconstruction of eco-city is carried out 14-20]. In Europe both scientific institutes and research centres, specializing in works in this area were created and work now (The European academy of the urban environment, etc.).

\section{Conclusion}

The analysis of traditional experience and achievements of modern technologies has allowed to define the eco-house as the system, capable to increase the ecological resource quicker, than natural eco-systems.

In the Russian Federation the process was not beyond design and construction of certain eco-houses yet. There is the operating time of experience in this area, accumulation of organizational and financial resources. Probably, in the nearest future the quantity of organizations will manage to carry out the construction of eco-cities in practice. However, the development of greening of the cities is generally conducted in Russia by the efforts of scientists so far. The government institutions demonstrate rather passive participation in this work and in spite of the fact, that some provisions, conformable concepts of sustainable development of settlements, is reflected in legislative documents of the Russian Federation, active state policy in this sphere is not conducted yet.

\section{References}

1. S. Joss, R. Cowley, M. de Jong, Tomorrow's City Today: Prospects for Standardising Sustainable Urban Development (University of Westminster, London, 2015)

2. European Centre for environment and health, ENHIS, Grant Agreement SPC 2003112 between the European Commission, (Bonn, Germany, 2005)

3. M. Roseland, Cities 14(4), 197-202 (1997)

4. D. Devuyst, How green is the city? (Columbia University Press, New York, 2001)

5. A. Zinatullin, E. Chibisova, Strategy of sustainable development of regions of Russia 5, 324-328 (2011)

6. S. Moffatt, N. Yabuki, H. Maruyama, World Bank Publications 2, 170 (2010)

7. E. Chibisova, Journal of International Scientific Publications: Economy \& Business 52, 600 (2015)

8. F. Caprotti, Cities 36, 10-36 (2014)

9. M.A. Bahauovna, M.A. Bahauovna, International Journal of Applied Engineering Research 11(9), 6808-6816 (2016)

10. J. R Krebs, J.D. Wilson, R. B. Bradbury, G.M. Siriwardena, Nature 400, 6745 (1999)

11. E. Chibisova, T. Meshcheryakova, Science Krasnoyarya 6(2-2), 146-148 (2017)

12. A.Tetio, Urban ecology (Academy, Moscow, 2008)

13. A. Mottaeva, World of economy and law 11, 7-14 (2011)

14. T. Meshcheryakova, Economy and entrepreneurship 8 (37), 334-336 (2013)

15. C.R. Palamar, Human Ecology Review 15 (1), 82-94 (2008) 
16. M. Rakočević, S. Popović, N. Ivanišević, Composites Part B 122, 202-218 (2017) doi: 10.1016/ j.compositesb.2017.03.044

17. N. Brookes, N. Ivanišević, A. Lukasiewicz, T. Sainati, C. lo Storto, Special Purpose Entities in Megaprojects, Transport and Urban Development, Action megaproject TU 1003 (University of Leeds, 2015) ISBN 978-0-9576805-3-1

18. M. Petronijević, A. Nikolić, M. Mikić, N. Ivanišević, Ahp Based Contractor Selection Procedure For Highway Infrastructure Projects In Serbia, 12th International Conference Organization, Technology and Management in Construction OTMC 2015, 206-214 (2015) ISBN 978-953-7686-06-2

19. O. Kalinina, O. Valebnikova, Advances in Intelligent Systems and Computing, 692 , pp 1315-1322 (2018) DOi - 10.1007/978-3-319-70987-1_139

20. Zaychenko, S. Gutman, O. Kalinina, Advances in Intelligent Systems and Computing, 692, pp 453-462 (2018) DOi - 10.1007/978-3-319-70987-1_48 